\title{
Thiram and Picloram as Entrapping Agents for Lead Depicted by Electrochemical Methods
}

\author{
Eliana M. A. Valle, ${ }^{a}$ Carolina Santamaría, ${ }^{b}$ Sergio A. S. Machado ${ }^{a}$ and \\ José M. Fernández *,b \\ anstituto de Química de São Carlos, Universidade de São Paulo, CP 780, \\ 13560-970 São Carlos-SP, Brazil \\ ${ }^{b}$ Departamento de Química y Edafología, Universidad de Navarra, Irunlarrea, 1, \\ 31080 Pamplona, Navarra, Spain
}

\begin{abstract}
A afinidade de dois pesticidas muito utilizados com diversas especificidades, isto é, o fungicida Thiram e o herbicida Picloram, por íons chumbo foi estudado por medidas eletroquímicas. O perfil voltamétrico de redissolução anódica para o íon metálico estudado foi significativamente afetado pela natureza química dos pesticidas (ligantes) e uma nova interpretação foi feita sobre a natureza, força e possível estequiometria dos complexos formados. Thiram causou um pronunciado efeito no sinal de redissolução do $\mathrm{Pb}$. Algoritmos de linearização dos dados de titulação permitiram calcular a constante de estabilidade condicional para o Thiram $\left(\log K^{\prime}=6,8\right)$ e Picloram $\left(\log K^{\prime}=6,0\right)$. Foi encontrado que ambos os pesticidas contribuíram para a formação dos respectivos complexos 1:1 com $\mathrm{Pb}$ em uma alta porcentagem (aproximadamente 83\%).
\end{abstract}

The affinity of two widely used pesticides of diverse specificities, i.e., the fungicide Thiram and the herbicide Picloram, for lead ions has been studied by an electrochemical approach. The anodic stripping voltammetric profile of the studied metallic ion was significantly affected by the chemical nature of pesticide (ligand) used and new light has been shed on the nature, strength and possible stoichiometry of formed complexes. Thiram caused a pronounced effect on the stripping signals of $\mathrm{Pb}$. Linearization algorithms of titration data with the metal allowed the conditional stability constant to be calculated for Thiram $\left(\log K^{\prime}=6.8\right)$ and Picloram $\left(\log K^{\prime}=6.0\right)$. It was found that both pesticides contribute to the formation of the respective $1: 1$ complexes with $\mathrm{Pb}$ in a high percentage $(\mathrm{ca} .83 \%)$.

Keywords: Thiram, Picloram, pesticides, lead, complexation

\section{Introduction}

Thiram [tetramethylthiuramdisulfide; Figure 1 (a)] and Picloram [4-amino-3,5,6-trichloro-2-pyridinecarboxylic acid; Figure 1 (b)] have been widely used as pesticides for decades. ${ }^{1,2}$ Thiram presents very high chemical and biological activities as fungicide preventing crop damage in the field and also harvested crops from deterioration in storage or transport. Picloram is highly effective in controlling many perennial weeds, poisonous plants, shrubs and other woody species.

Both pesticides are hazardous to the environment and once they have been applied, physicochemical processes such as adsorption/desorption or any other

*e-mail: jmfdez@unav.es<smiles>CN(C)C(=S)SSC(=S)N(C)C</smiles>

(a)<smiles>Nc1c(Cl)c(Cl)nc(C(=O)O)c1Cl</smiles>

(b)
Figure 1. Thiram (a) and Picloram (b) schematic representations.

chemical or biological transformations determine their fate. ${ }^{3}$ Persistence of these compounds in the soil is a major concern and many researchers have developed reliable methods for the determination in a variety of matrices and using many different techniques: solid phase extraction (SPE) coupled with liquid chromatography ${ }^{4}$ or SPE with gas chromatography and mass spectrometry, ${ }^{5}$ 
HPLC, ${ }^{6}$ colorimetry, ${ }^{7}$ spectrophotometry, ${ }^{8}$ electrochemical techniques ${ }^{9,10}$ and enzyme linked immunoassay (ELISA). ${ }^{11}$

On the other hand, both Thiram and Picloram are well known complexing ligands for metals ${ }^{12,13}$ and this ability has allowed the commercialisation of pesticides which include in their formulation a metallic ion, as occurs with Ziram, the $\mathrm{Zn}$ enriched analogue of Thiram. ${ }^{14}$ This metal-pesticide interaction is an important feature since it could modify the toxicity of the corresponding compound. Depending on the lability of the complex formed, toxicity might increase, decrease or remain unaffected. ${ }^{14}$ This modification of the toxicity degree by interaction with other molecules has already been proposed and applied to field, taking advantage of the strong interactions established between pesticides and clays and/or organic matter of soil. ${ }^{15,16}$ Such association facilitates the immobilisation and degradation of those organic molecules by the action of sunlight, microorganisms or chemical reactions but degradation products may also be toxic.

Metal bioavailability depends on its chemical form and it is strongly affected by the presence of natural and/ or anthropogenic substances acting as trapping agents. Usually, studies carried out on natural samples refer to total metal concentration and, accordingly, information supplied fails short of the whole picture. Depending on the degree of complexation as well as on the strength of the binding of the metal to the ligands, a significant fraction of the total metal could be unavailable for common uptaking pathways. Metal-ligand interactions have been thoroughly studied electrochemically in natural waters, ${ }^{17}$ and soil solutions. ${ }^{18}$ However, literature concerning complexing characterization of pesticides with metals is amazingly scarce, although metal complexes will be naturally formed in most soils where pesticides have been applied. Thiram shows a peculiar redox behaviour on mercury and gold electrodes, because of the presence of a dithiocarbamate group. ${ }^{19,20}$ Picloram shows an irreversible electrochemical behaviour which can be followed on $\mathrm{Hg}$ electrodes, as published elsewhere. ${ }^{9,21,22}$ In fact, several procedures concerning the determination ${ }^{9,19,23}$ or characterisation of solubility and $\mathrm{pKa}^{24}$ of the pesticide have been developed.

The aim of the present work is to electrochemically characterise the complexes formed between lead and the above mentioned pesticides, either Thiram or Picloram. The electrochemical response of both molecules on $\mathrm{Hg}$ electrodes is discussed and their effects on metal accumulation and stripping are studied. The mathematical transformation of the data through the corresponding algorithms, Langmuir ${ }^{25}$ and Scatchard, ${ }^{26}$ allowed the calculation of physicochemical parameters such as conditional complex formation constants or ligand availability in the case of the herbicide.

\section{Experimental}

\section{Materials}

Standard $\mathrm{Pb}$ solutions were prepared by adequate dilution of $1000 \mathrm{mg} \mathrm{L}^{-1}$ Certipure (Merck) stock solution in $\mathrm{pH} 4.0$ acetate/acetic buffer. Nitric acid was further distilled in our laboratory under sub-boiling conditions. Plastic material (polypropylene) was washed with deionised distilled water, soaked for $24 \mathrm{~h}$ in $10 \% \mathrm{HNO}_{3}$ and finally, rinsed several times with deionised distilled and ultrapure water. Glassware was washed exactly in the same way, but soaked in $5 \% \mathrm{HNO}_{3}$.

Both pesticides Thiram (Chem Service) and Picloram (Sigma Aldrich) were used without further purification. They present very low solubilities in water and, therefore, concentrate solutions $5.0 \times 10^{-3} \mathrm{~mol} \mathrm{~L}^{-1}$ were prepared in pure ethanol. Aqueous dilutions of these concentrate solutions were used throughout the study and prepared with $\mathrm{pH} 4.0$ acetate/acetic buffer.

\section{Apparatus}

Voltammetric measurements were performed in an Autolab PGSTAT12 system (Ecochemie, B. V., Utrecht, Netherlands) connected to a Metrohm (Herisau, Switzerland) 663 VA stand, equipped with a static mercury drop electrode (SMDE). A conventional three-electrode arrangement, consisting of a glassy carbon rod as the auxiliary electrode, an $\mathrm{Ag} / \mathrm{AgCl}\left(3 \mathrm{~mol} \mathrm{~L}^{-1} \mathrm{KCl}\right)$ system as the reference electrode and the Metrohm multimode mercury electrode operating with a mercury drop of $0.33 \mathrm{~mm}^{2}$ was used. Titration data were automatically collected by means of a 765 Dossimat (Metrohm) coupled to a 730 Sample Changer (Metrohm).

Total metal content was measured with an ICP-MS Agilent 7500a.

\section{Procedures}

Cyclic voltammetry was used to study both pesticides in the absence as well as in the presence of $\mathrm{Pb}$ at a scan rate of $25 \mathrm{mV} \mathrm{s}^{-1}$.

Differential pulse scanning mode was used throughout to perform the anodic stripping voltammetry measurements. The general instrumental settings were as follows: deposition time $\left(\mathrm{t}_{\mathrm{d}}\right)$ : $60 \mathrm{~s}$ under $3000 \mathrm{rpm}$ stirring; equilibration time $\left(\mathrm{t}_{\mathrm{eq}}\right): 20 \mathrm{~s}$. Specific settings related to the study of pesticide behaviours are described in the corresponding figure legends. In general, for quantification purposes pulse amplitude of $50 \mathrm{mV}$ was used, whereas 
pulse amplitude of $15 \mathrm{mV}$ was used for the pesticides electrochemical behaviour studies.

Titration curves were done on $1.0 \times 10^{-6} \mathrm{~mol} \mathrm{~L}^{-1}$ of either Thiram or Picloram by adding successive spikes of $50 \mu \mathrm{L}$ of $1.45 \times 10^{-5} \mathrm{~mol} \mathrm{~L}^{-1}$ of $\mathrm{Pb}^{2+}$ standard solution.

Total metallic ion concentration measured for a $1.0 \times 10^{-6} \mathrm{~mol} \mathrm{~L}^{-1}$ Picloram in $\mathrm{pH} 4.0$ acetate buffered solution was $2.03 \times 10^{-9} \mathrm{~mol} \mathrm{~L}^{-1}$.

\section{Results and Discussion}

\section{Thiram}

Literature is abundant on electrochemical studies of the reduction mechanism of the S-S containing molecules on the $\mathrm{HMDE}^{10,27}$ and it continues to focus the attention of researchers intrigued by the adsorption and subsequent reduction of such compounds. ${ }^{28}$

Preliminary experiments were carried out in order to find the appropriate electrolyte that closest represents the natural soil conditions ${ }^{29}$ in which the fungicide is commonly used. An acetate/acetic buffer solution, $\mathrm{pH}$ 4.0, was found to provide a complexing-free background $\mathrm{d}^{30}$ in which all stripping signals were easily quantifiable.

Thiram electrochemical behaviour has been studied under the same conditions, for they will be used later for the study of lead-Thiram interactions.

A cyclic voltammogram obtained for a $1.2 \times 10^{-5} \mathrm{~mol} \mathrm{~L}^{-1}$ Thiram in a pH 4.0 (acetate buffered solution) shows, on one side, a quasi-reversible signal around $-0.5 \mathrm{~V}$ - related to the S-S moiety classical response $\mathrm{e}^{10,27}-$ and, on the other side, an oxidation signal at $c a .-0.2 \mathrm{~V}$ ascribed to the oxidation of the $\mathrm{Hg}$ electrode in the presence of the Thiram. ${ }^{27}$ When the scan was reversed on the cathodic sense, a large signal was obtained close to $-0.4 \mathrm{~V}$ (not showed). If cyclic experiments were started in the negativegoing direction, the signal at $-0.4 \mathrm{~V}$ is absent in the first cycle; it only shows up in subsequent sweeps, once the corresponding oxidized species had been allowed to degenerate in the first scan. These findings are consistent with the classical proposed mechanism in which $\mathrm{Hg}$ is oxidized and incorporated onto the disulphide linkage and subsequently suffers reduction at the above mentioned potential. ${ }^{31}$ Since $\mathrm{Pb}$ anodic stripping signal is expected to appear at $c a .-0.4 \mathrm{~V},{ }^{32}$ its preconcentration on the mercury electrode should be forced by applying a potential at least $200 \mathrm{mV}$ more negative. Accordingly, we have used a value of $-0.6 \mathrm{~V}$ for the accumulation of the amalgamated $\mathrm{Pb}(\mathrm{Hg})^{0}$. Such a choice for the preconcentration step would induce the reduction of Thiram when it reaches the surface of the electrode. The influence of the accumulation potential was checked by doing experiments at $-1.2 \mathrm{~V}$ too, and obtained results did not differ significantly as further discussed below.

\section{Electrochemical behaviour of lead in Thiram solutions}

Lead was selected for its well known presence in Brazilian soils ${ }^{33,34}$ as well as for its distinct electrochemical response on $\mathrm{Hg}$ electrodes.

Metal $(\mathrm{Pb})$-ligand (Thiram) interactions will be approached through the measurement of stripping current of amalgamated lead once it has been deposited on the mercury electrode from ligand-containing solutions. As compared with stripping responses obtained in buffered (ligand-free) solutions, the magnitude of the peaks will differ depending on the affinity of the ligand for the metal. Thus, if the $\mathrm{Pb}$ is completely retained by the Thiram in solution, it would not be able to amalgamate on the mercury electrode and, consequently, no stripping signal would be recorded (or, at least, its magnitude would be diminished). As metal concentration increases, the complexing capacity of the fungicide decreases and when saturation of ligand complexation capacity is reached, a normal stripping peak will start to develop. A plot of peak current $v s$. concentration of added metal will show two different segments with different slopes, the second one being larger and similar to that obtained in buffered aqueous (ligand-free) solutions.

Differential pulse was chosen as potential scan mode for convenient peak-shape signals to be recorded and best conditions were obtained for a pulse amplitude of $50 \mathrm{mV}$ and a scan rate of $20 \mathrm{mV} \mathrm{s}^{-1}$. Since the formation of metallic ions-Thiram complexes may follow a sluggish kinetics, different equilibration times were assayed so that optimized conditions for complex formation were achieved prior to the electrochemical measurements. In general, after 5 min no large dependence of the stripping current upon equilibration time was found so this value was chosen as optimum. A pre-concentration time of $1 \mathrm{~min}$ was used throughout.

Figure 2 shows the stripping pattern obtained for increasing amounts of a $1.45 \times 10^{-5} \mathrm{~mol} \mathrm{~L}^{-1} \mathrm{~Pb}\left(\mathrm{NO}_{3}\right)_{2}$ standard spiked onto a solution containing a fixed concentration of $2.0 \times 10^{-6} \mathrm{~mol} \mathrm{~L}^{-1}$ Thiram (base line), when a pre-concentration potential of $-0.600 \mathrm{~V}$ was employed.

In normal conditions one would expect a stripping signal of lead at $-0.4 \mathrm{~V}$ which magnitude would increase with added lead concentration. However, a distinct signal is recorded at $-0.2 \mathrm{~V}$, that increases regularly with spiked $\mathrm{Pb}$. These findings correlate well with the fact that the pre-concentration step of stirred solution under a fixed potential of $-0.600 \mathrm{~V}$ favours the reduction of Thiram on the electrode surface with the formation of two $\mathrm{N}, \mathrm{N}$-dimethyl- 


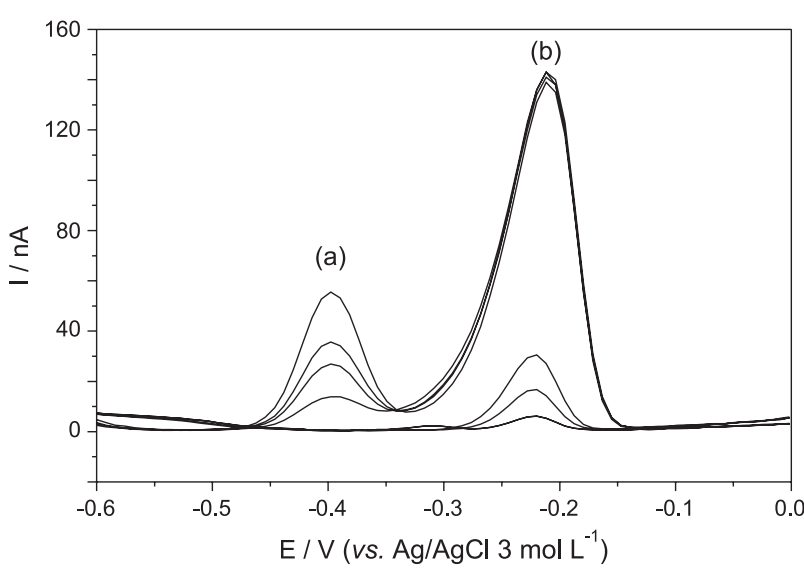

Figure 2. Differential pulse voltammograms of a $2.0 \times 10^{-6} \mathrm{~mol} \mathrm{~L}^{-1}$ Thiram $\mathrm{pH} 4.0$ buffered solution (base line) spiked with $\mathrm{Pb}\left(\mathrm{NO}_{3}\right)_{2}$ yielding final increasing concentrations of: $1.4 \times 10^{-7} \mathrm{~mol} \mathrm{~L}^{-1} ; 2.8 \times 10^{-7} \mathrm{~mol} \mathrm{~L}^{-1}$; $1.9 \times 10^{-6} \mathrm{~mol} \mathrm{~L}^{-1} ; 2.1 \times 10^{-6} \mathrm{~mol} \mathrm{~L}^{-1} ; 2.2 \times 10^{-6} \mathrm{~mol} \mathrm{~L}^{-1}$; $2.4 \times 10^{-6} \mathrm{~mol} \mathrm{~L}^{-1}$. Deposition potential $\mathrm{E}_{\mathrm{d}}=-0.600 \mathrm{~V} ;$ scan rate $=20 \mathrm{mV} \mathrm{s}^{-1}$; pulse amplitude $=50 \mathrm{mV}$.

dithiocarbamate (DMDTC) moieties. The scheme of such process is showed in Figure 3A, following previously reported electrode reactions..$^{35}$

The cleavage of S-S bond of Thiram by metallic surfaces like $\mathrm{Hg}$ or $\mathrm{Ag}$ is a common mechanism as already evidenced by surface-enhanced Raman spectroscopy. ${ }^{36}$ The DMDTC molecules that remain either adsorbed or in the close vicinity of the $\mathrm{Hg}$ electrode are available for coordination of $\mathrm{Pb}^{2+}$ ions when they are stripped from its amalgamated form on the $\mathrm{Hg}$ electrode, as depicted in Figure 3B.

Thus, initial stripping peaks expected at $-0.4 \mathrm{~V}$ rather surge at $-0.2 \mathrm{~V}$, according to the above proposed mechanism. This behaviour makes the initial portion of the titration curve (Figure 4A) flat instead of the usual smoothly increasing slope (as is the case when preconcentration is carried out at $-1.2 \mathrm{~V}$; see below, Figure 5B). The plot of peak (b) current increases linearly with added $\mathrm{Pb}$ up to a point in which it stabilises (see Figure 4B). The plateau of the current is reached for a 1:1 ratio of molar concentrations $\left(2.0 \times 10^{-6} \mathrm{~mol} \mathrm{~L}^{-1}\right.$ each $)$ in solution of both $\mathrm{Pb}$ and Thiram.

The analysis of Figure 4A reveals that no linearization algorithms could be applied since the initial spikes of $\mathrm{Pb}$ fails to provide any measurable current at this potential $(-0.4 \mathrm{~V})$. However, from the second track of the curve, one can extrapolate an approximate value of $2.0 \times 10^{-6} \mathrm{~mol} \mathrm{~L}^{-1}$ concentration of $\mathrm{Pb}$ that saturates the complexing capacity of the ligand present in solution (that is also $\left.2.0 \times 10^{-6} \mathrm{~mol} \mathrm{~L}^{-1}\right)$. Consequently a 1:1 stoichiometry can be proposed in good agreement with the conclusions derived from Figure 4B.

When a more negative accumulation potential was used, that is to say the preconcentration step was carried out at $-1.200 \mathrm{~V}$, a diverse picture was obtained (Figure 5A), in which peak (b) is scarcely developed whereas peak (a) increases constantly.

The following-up of the stripping current of peak (a) gives rise to the titration curve plotted in Figure 5B in which two different patterns are featured. The first portion of the graph represents the mentioned situations in which added $\mathrm{Pb}^{2+}$ is partially retained in solution by the complexing Thiram, thus allowing a certain portion of metal to be amalgamated on the $\mathrm{Hg}$ electrode and afterwards redissolved. Once the coordinating ability of Thiram is saturated with $\mathrm{Pb}^{2+}$, further increase in the metal ion begins to produce a much larger current as seen in the second track of the titration curve. This is the usual situation in which<smiles>CN(C)C(=S)SSC(=S)N(C)C</smiles>

Thiram

DMDTC

(A)

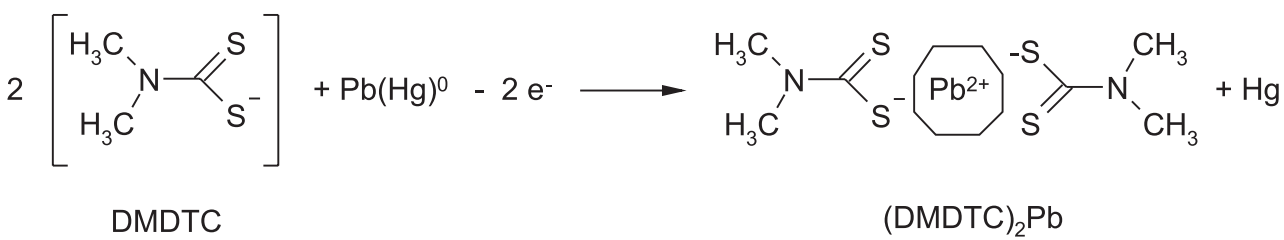

(B)

Figure 3. Schematic representation of (A) S-S bond cleavage on $\mathrm{Hg}$ surface polarized at $-0.600 \mathrm{~V}$; (B) of the formation of (DMDTC) ${ }_{2} \mathrm{~Pb}$ on the electrode surface. 

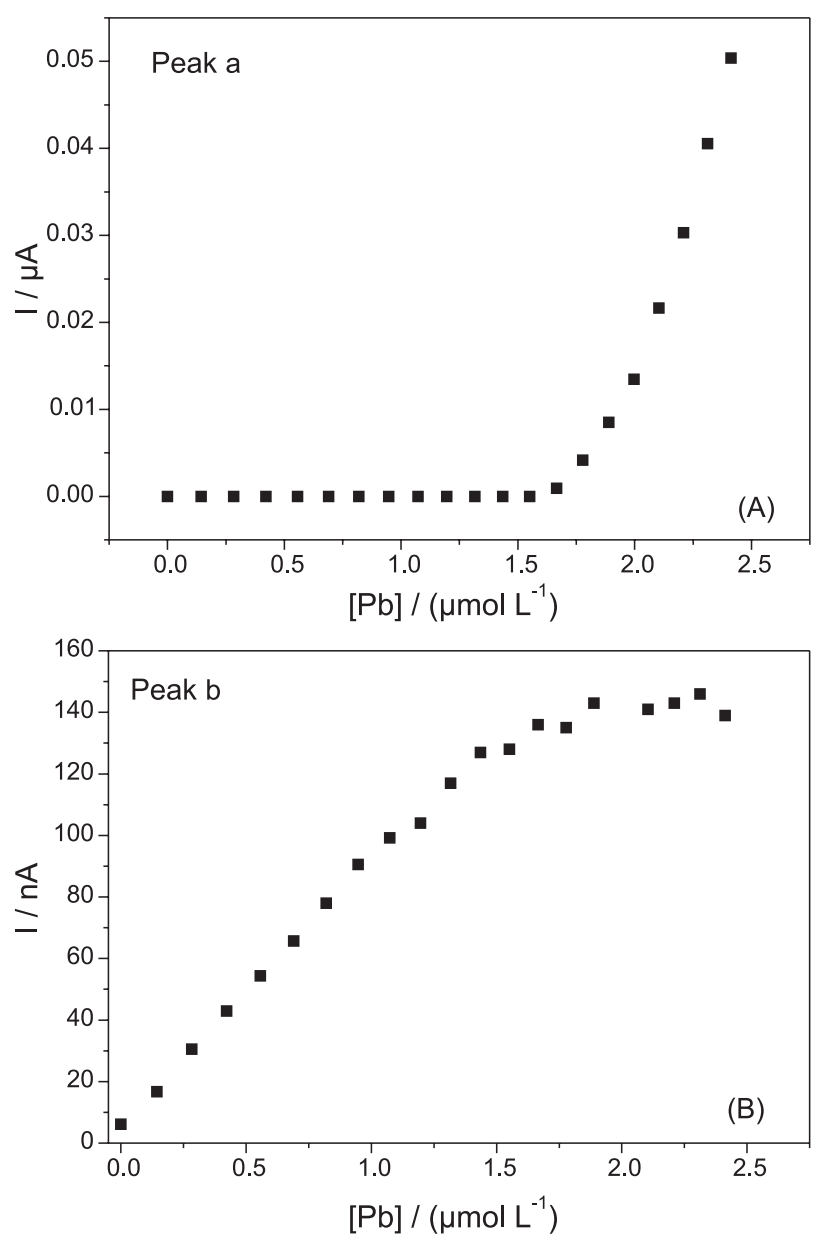

Figure 4. Titration curves (evolution of peak current) for both peak $\mathbf{a}$ at $-0.4 \mathrm{~V}$ (A) and peak b at $-0.2 \mathrm{~V}$ (B) in Figure 2.

reduction of $\mathrm{Pb}^{2+}$ onto the electrode to form amalgamated $\mathrm{Pb}(\mathrm{Hg})^{0}$ occurs from the excess of metallic ion in solution (equation 1).

$\mathrm{Pb}^{2+}+2 \mathrm{e}^{-}+\mathrm{Hg} \rightarrow \mathrm{Pb}(\mathrm{Hg})^{0}$

The extrapolation of the second, and more steep, linear portion yields an abscissa intercept of $c a .1 \mu \mathrm{mol} \mathrm{L}{ }^{-1}$ of $\mathrm{Pb}$, what is coincident with the assayed Thiram concentration $\left(1.0 \times 10^{-6} \mathrm{~mol} \mathrm{~L}^{-1}\right)$ indicating a 1:1 complex formation. This stoichiometry matches the one found when the procedure was done by preconcentrating at $-0.6 \mathrm{~V}$.

Besides, the previously described process taking place at $-0.2 \mathrm{~V}$ still is perceived, but in a much smaller extent, as reflected in the first two experimental values of the titration curve presented in Figure 5B. This could be understood in terms of charge repulsion of the reduced DMDTC moieties on the much more negatively charged $\mathrm{Hg}$ electrode. As a consequence the ability to form RS-Pb-SR complexes on the adsorbed state is lost, or at least it is diminished in a large proportion.
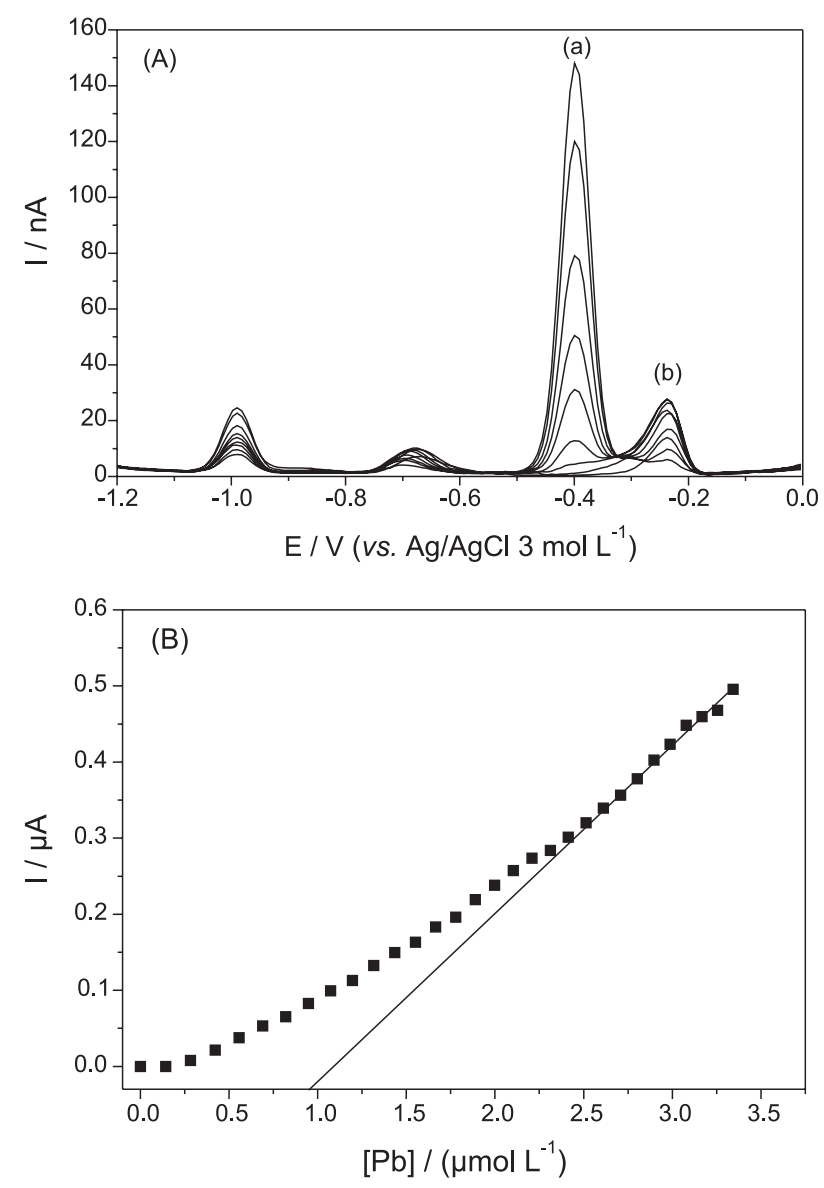

Figure 5. (A) Differential pulse voltammograms of a $1.0 \times 10^{-6} \mathrm{~mol} \mathrm{~L}^{-1}$ Thiram $\mathrm{pH} 4.0$ buffered solution with successive spikes of $\mathrm{Pb} . \mathrm{E}_{\mathrm{d}}=-1.200 \mathrm{~V}$; scan rate $=20 \mathrm{mV} \mathrm{s}^{-1}$; pulse amplitude $=50 \mathrm{mV}$; (B) Titration curve for peak a in Figure 5A.

Under these experimental conditions it has been possible to apply the Langmuir linearization procedure adjusted to a 1:1 stoichiometry, from which a ligand concentration of $8.34 \times 10^{-7} \mathrm{~mol} \mathrm{~L}^{-1}$ could be estimated, in very good agreement with the real value of $1.0 \times 10^{-6} \mathrm{~mol} \mathrm{~L}^{-1}$. Furthermore, a conditional stability constant was calculated to be $10^{6.76}$.

\section{Picloram}

Picloram shows a reduction wave on mercury electrodes that has been ascribed to desorption coupled with catalytic characteristics and for which different mechanisms were proposed. ${ }^{9,21}$ Its ability to complex $\mathrm{Cu}$ and $\mathrm{Fe}$ has been checked by polarographic means ${ }^{22}$ and different approaches have been reported for the determination of its pKa. ${ }^{24}$ For the purpose of this study, we have chosen the same buffer as before in order to mimic that of Brazilian soils that is $c a$. 4 . Thus, a pH 4.0 acetate buffer renders a deprotonated Picloram with best binding dispositions towards metallic ions. Figure 6A 
shows a cyclic voltammogram for Picloram recorded under our experimental conditions which shows a single reduction process at $-1.050 \mathrm{~V}$ with no reversible pair, leaving a clear potential window to explore the anodic stripping voltammograms of assayed metal.

Cyclic voltammograms obtained for lead in the absence and presence of Picloram are depicted in Figure 6B. As proved in the previous experiment (Figure 6A) Picloram does not produce any electrochemical signal on the potential window used for $\mathrm{Pb}$, and its presence only provokes a slight displacement on $\mathrm{Pb}$ peak potential as well as a small decrease in its peak current.

Electrochemical measurements carried out in the pulse mode yielded a more convenient peak shape with an improved sensitivity, and this mode was chosen hence forward. Peak potential shift caused by the presence of Picloram in the same ratio (Picloram to $\mathrm{Pb}, 4: 1$ ), was $c a$. $20 \mathrm{mV}$ when measured in the differential pulse mode (Figure 6C).

Complexation studies were done by preconcentrating the metal onto the mercury electrode at $-0.600 \mathrm{~V}$ from both ligand-free lead solutions (classical calibration plot) and in the presence of a fixed amount of Picloram present (titration curve). Linear calibration graphs were obtained in the acetate buffer solution in the absence of the pesticide and those data will prove useful for comparison purposes with the stripping signals obtained in the presence of Picloram (vide infra).

Picloram was titrated with increasing concentration of $\mathrm{Pb}$, and the metal stripping signals were monitored as shown in Figure 7, where both raw and algorithmstransformed data are plotted. Figure 7A displays a change in slope indicative of the different pathways followed by the metal in the accumulation step on the electrode, depending on whether it is in defect or excess with respect to the ligand concentration. ${ }^{30}$

From these data one can approximately - by means of the linearization algorithms ${ }^{25,26}$ - derive the complexing capacity of Picloram, the molar ratio of the formed complex and the conditional stability constant for the complex.

The conditional stability constant found ( $\log \mathrm{K}^{\prime}$ ) was around 6.0, showing a formation of a strong complex. As it can be seen, $\mathrm{Pb}$ was found to form a dissociable 1:1 complex with Picloram in which ligand involved in the detectable complex was calculated to be up to $95 \%$.

These findings are in good agreement with the different values measured for the slopes of the calibration and titration plots. The slope of the first portion of the titration plot undergoes a marked decrease with respect to the slope of the calibration plot $\left(0.106 v s .0 .185 \mu \mathrm{A} \mu \mathrm{mol}^{-1} \mathrm{~L}\right)$. When attention is focused on the second linear portion of the titration plot, its slope value comes closer to that of the calibration graph $\left(0.175\right.$ vs. $\left.0.185 \mu \mathrm{A} \mu \mathrm{mol}^{-1} \mathrm{~L}\right)$

Calculated conditional constants by either methodology were quite similar and those values are close to those found in literature. ${ }^{22}$
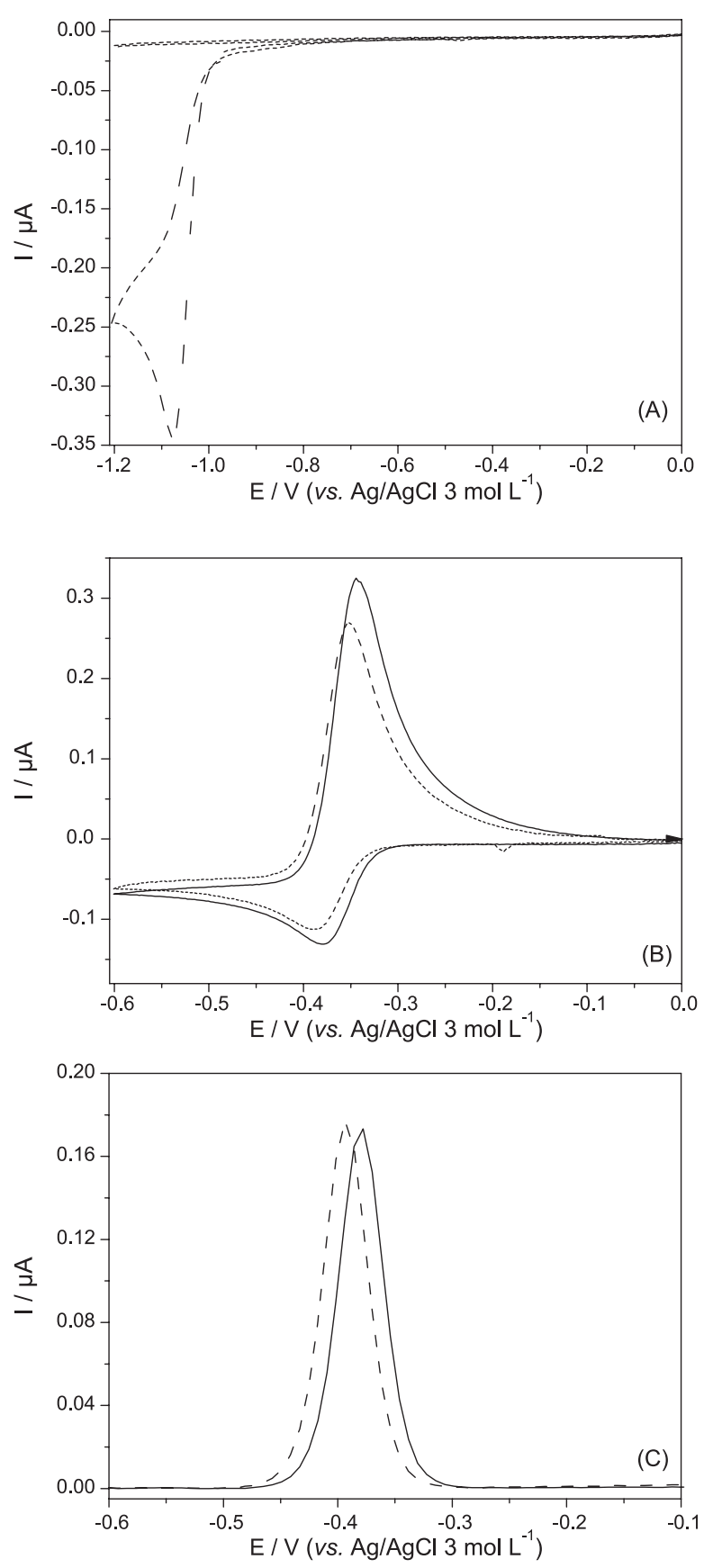

Figure 6. (A) Cyclic voltammograms for a $\mathrm{pH} 4.0$ buffer blank solution (continuous line) and for a pH 4.0 buffered $1.0 \times 10^{-4} \mathrm{~mol} \mathrm{~L}^{-1}$ Picloram solution (dotted line); scan rate: $25 \mathrm{mV} \mathrm{s}^{-1}$; (B) Cyclic voltammograms obtained for $\mathrm{pH} 4.0$ buffered $1.0 \times 10^{-4} \mathrm{~mol} \mathrm{~L}^{-1} \mathrm{~Pb}\left(\mathrm{NO}_{3}\right)_{2}$ (continuous line) and in the presence (dotted line) of $4.0 \times 10^{-4} \mathrm{~mol} \mathrm{~L}^{-1}$ Picloram; scan rate: $25 \mathrm{mV} \mathrm{s}^{-1}$; (C) Differential pulse voltammograms obtained for $3.0 \times 10^{-6} \mathrm{~mol} \mathrm{~L}^{-1} \mathrm{pH} 4.0$ buffered solutions of $\mathrm{Pb}\left(\mathrm{NO}_{3}\right)_{2}$ in the absence (continuous line) and presence (dotted line) of $1.2 \times 10^{-5} \mathrm{~mol} \mathrm{~L}^{-1}$ Picloram. Pulse amplitude $=15 \mathrm{mV} . \mathrm{E}_{\mathrm{d}}=-0.600 \mathrm{~V}$. 

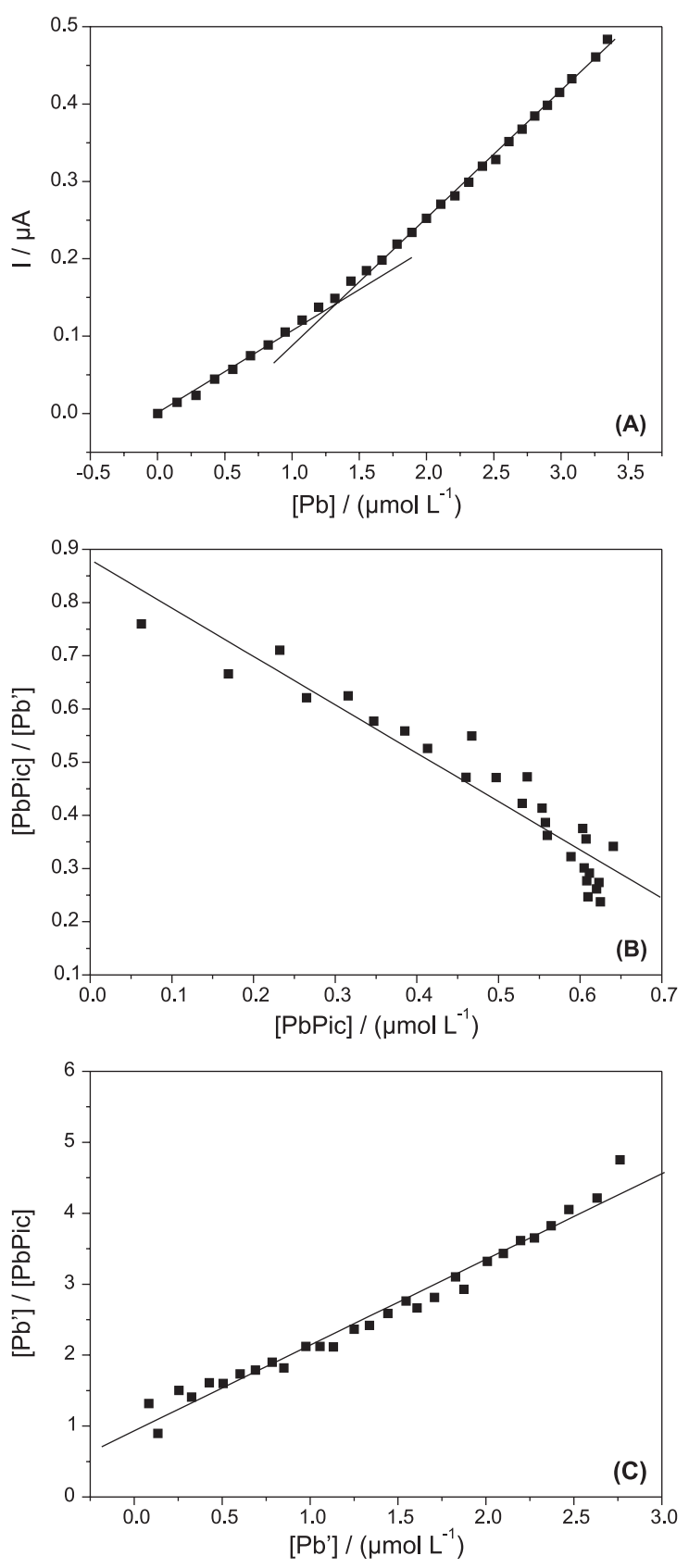

Figure 7. Titration curve for a $\mathrm{pH} 4.0$ buffered $1.0 \times 10^{-6} \mathrm{~mol} \mathrm{~L}^{-1}$ Picloram solution with increasing spikes of $\mathrm{Pb}^{2+}(\mathrm{A})$ and its corresponding Scatchard (B) and Langmuir (C) transformations.

\section{Conclusions}

Lead-Thiram interactions studied on the mercury electrode are affected by the peculiar electrochemical response of the ligand on that electrode material. Thiram proved to form a 1:1 complex with $\mathrm{Pb}$ in solution, irrespective of the electrochemical response and was monitored after competitive accumulation of $\mathrm{Pb}$ onto the $\mathrm{Hg}$ electrode either at $-0.6 \mathrm{~V}$ or at $-1.2 \mathrm{~V}$. Although discussed stripping pathways are diverse under those different conditions, the results are consistent in both cases with a 1:1 stoichiometry.

Picloram also forms a 1:1 complex with $\mathrm{Pb}$ with a high percentage of availability. Complexation studies by Picloram were rendered simple thanks to its non-interfering electrochemical behaviour.

Although both stoichiometry and ligand involvement were similar for both pesticides, Thiram showed highest affinity for $\mathrm{Pb}$, its $\log \mathrm{K}$ ' being almost one order of magnitude higher (6.87 vs. 6.04).

\section{Acknowledgements}

E. M. A.Valle acknowledges the Coordenação de Aperfeiçoamento de Pessoal de Nível Superior (CAPES, Brazil) for funding her stay at the University of Navarra. Authors acknowledge Dr. E. Lasheras for the ICP-MS measurements.

\section{References}

1. Klopping, H. L.; Van der Kerk, G. J.; Recl. Trav. Chim. Pays-Bas Belg. 1951, 70, 917.

2. Goring, C. A. I.; Youngson, C. R.; Hamaker, J. W.; Down to Earth 1965, 20, 13.

3. Matolcsy, G.; Ndasy, M.; Andriska, V.; Pesticide Chemistry, Elsevier:Amsterdam, 1988.

4. Pipkin, W.; van Hout, P.; Anal. Chem. 1997, 69, A21.

5. Hankemeier, T.; van Leeuwen, S. P. J.; Vreuls, R. J. J.; Brinkman, U. A. Th.; J. Chromatogr., A 1998, 81, 117.

6. Sánchez-Brunete, C.; De Cal, A.; Melgarejo, P.; Tadeo, J. L.; Int. J. Environ. Anal. Chem. 1989, 37, 35.

7. Malik, A. K.; Paul, Y.; Rao, A. L. J.; Purl, B. K.; Int. J. Environ. Stud. 1991, 38, 199.

8. Verma, B. C.; Sood, R. K.; Sharma, D. K.; Sidhu, H. S.; Chauhan, S.; Analyst 1984, 109, 649.

9. Massaroppi, M. R. C.; Machado, S. A. S.; Avaca, L. A.; J. Braz. Chem. Soc. 2003, 14, 113.

10. Rupp, E. B.; Zuman, P.; Sestáková, I.; Horák, V.; J. Agric. Food Chem. 1992, 40, 2016.

11. Queffelec, A. L..; Boisdé, F.; Larue, J. P.; Haelters, J. P.; Corbel, B.; Thouvenot, D.; Nodet, P.; J. Agric. Food Chem. 2002, 49, 1675.

12. Hulanicki, A.; Talanta 1967, 14, 137.

13. Michaud, H. H.; Hoggard, P. E.; J. Agric. Food Chem. 1988, 36, 208.

14. Borg, K.; Tjaelve, H.; Toxicol. Lett. 1988, $42,87$.

15. Barriuso, E. ; Calvet, R.; Int. J. Environ. Anal. Chem. 1992, 46, 117.

16. Close, M. E.; Pang, L.; Watt, J. P. C.; Vincent, K. W.; Geoderma 1998, 84, 45. 
17. Gun, J.; Salaun, P.; van den Berg, C. M. G.; Anal. Chim. Acta 2006, 571,86 .

18. Pelfrêne, A.; Gassama, N.; Grimaud, D.; Electroanalysis 2008, $20,841$.

19. Sevilla, M. T.; Procopio, J. R.; Pinilla, J. M.; Hernández, L.; Electroanalysis 1990, 2, 475.

20. Hernández-Olmos, M. A.; Agüí, L.; Yáñez-Sedeño, P.; Pingarrón, J. M.; Electrochim. Acta 2000, 46, 289.

21. Whittaker, J. W.; Osteryoung, J.; J. Agric. Food Chem. 1980, 28,89 .

22. Chang, I. K.; Foy, C. L.; Pestic. Biochem. Physiol. 1982, 18, 141.

23. dos Santos, L. B. O.; Masini, J. C.; Talanta 2007, 72, 1023.

24. Osteryoung, J.; Whittaker, J. W.; J. Agric. Food Chem. 1980, 28,95 .

25. Van den Berg, C. M. G.; Kramer, J. R.; Anal. Chim. Acta 1979, 106, 113.

26. Scatchard, G.; Ann. N. Y. Acad. Sci. 1949, 51, 660.

27. Brand, M. J. D.; Fleet, B.; Analyst 1970, 95, 1023.

28. Giannakopoulos, E.; Deligiannakis, Y.; Langmuir 2007, 23, 2453.
29. Miyazawa, M.; Pavan, M. A.; Ziglio, C. O.; Franchini, J. C.; Braz. Arch. Biol. Technol. 2001, 44, 149.

30. Salinas, I.; Esparza, I.; Gómez, S.; Santamaría, C.; Fernández, J. M.; Electroanalysis 2005, 17, 469.

31. Heyrovský, J.; Kuta, J.; Principles of Polarography, Academic Press: New York, 1965.

32. Merkoçi, A.; Vasjari, M.; Fàbregas, E.; Alegret, S.; Mikrochim. Acta 2000, 135, 29.

33. de Matos, A. T.; Fontes, M. P. F.; da Costa, L. M.; Martinez, M. A.; Environ. Pollut. 2001, 111, 429.

34. Fontes, M. P. F.; Gomes, P. C.; Appl. Geochem. 2003, 18, 795.

35. Morf, P.; Raimondi, F.; Nothofer, H. G.; Schnyder, B.; Yasuda, A.; Wessels, J. M.; Jung, T. A.; Langmuir 2006, 22, 658.

36. Sanchéz-Cortés, S.; Vasina, M.; Francisco, O.; Garcia-Ramos, J. V.; Vib. Spectrosc. 1998, 17, 133.

Received: October 22, 2009 Web Release Date: March 4, 2010

FAPESP helped in meeting the publication costs of this article. 